
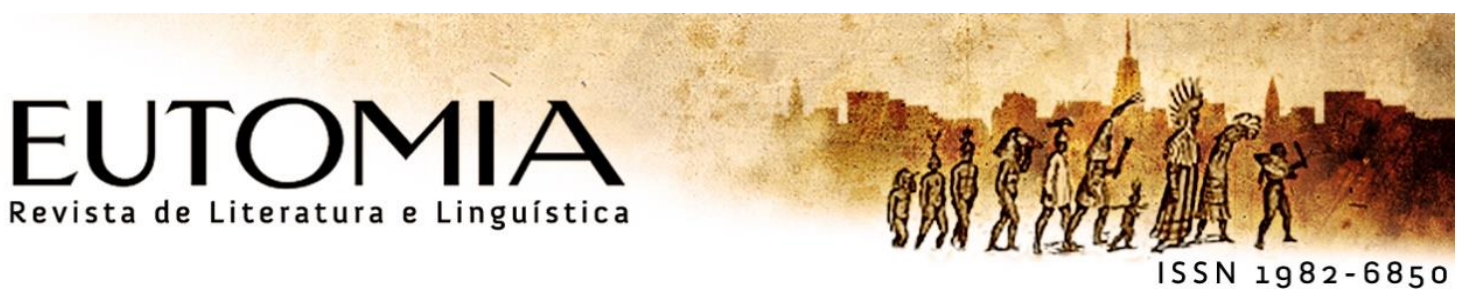

\title{
Os vivos(?) E os mortos [fragmento]
}

Fernando Monteiro ${ }^{\mathrm{i}}$

\section{Siamo tutti in pericolo}

[Estamos todos em perigo]

-- PIER PAOLO PASOLINI, em entrevista a Furio Colombo, um dia antes de ser brutalmente trucidado em 2 de novembro de 1975, na periferia romana (praia de Ostia).

\section{O que aconteceu conosco?...}

Foi por nós,

por esta gente assustada,

por este país doente

que assim desapareceram

tantos \& tantos "desaparecidos"

durante os anos que mataram

o Brasil também a golpes

e golpes?

Se foi (oh, o sangue não seca, não seca nos olhos) nós não merecíamos 
[de modo nenhum]

essas jovens vidas sacrificadas,

nós não remanescemos à altura

desses mortos com selvageria

à solta,

às vezes numa só sessão

detrás da porta de um quarto

fechado sobre suor,

urina,

fezes

e plasma.

Este poema pergunta

e tenta responder (ao mesmo tempo)

daquela forma de Pier Paolo Pasolini,

o Cristo do Século XX.

Eu tento ser igualmente direto

e claro no extremo desconforto,

embora não queira ser torturado

e assassinado conforme foi PPP

(aqui no Brasil significa

Pobre Padre Preto como Henrique,

o sacerdote eliminado

no Recife de Dom Hélder,

pela ditadura das casas dos mortos).

Quem foi esse padre?

Não foi ninguém,

para os tempos de Agora.

Neste tempo Indiferente de Hoje, 
somos o oposto daquela geração

generosa que terminou na serra sinistra

e noutros "Codões" que ainda restam

ignorados de um modo ou de outro.

Pois o nosso é um tempo de morte

na consciência que se aplaca.

O nosso é um tempo velho

de desmonte

da memória dos mais novos.

O nosso é um tempo (para muitos

jovens)

de ter,

de qualquer modo ter

rendimentos compatíveis com a troca

da Realidade pelo Game

em jogos de NETs-nerds.

O nosso tempo...

Por que eu estou reiterando

o já reiterado?

Por que estou escrevendo

este poema que não é um poema (repito)

apenas para que se entenda

que estamos numa época muitíssimo dura,

nesta dobra de dois-zero-dois-

zero de coragem temerária

dos que foram caçados e transpotados

para a Casa da Morte de ânimo exaltado 
para o massacre:

"desta casa não sai vivo ninguém

que tenha alimentado a mais vã

esperança" (nas palavras dos

algozes mais tarde medalhados).

O ânimo que resta

quanto a nós, nesta hora,

parece ser de recuo

e recusa de morrer para escapar

de viver apenas e tão somente

por nada

ou quase nada

na espuma dos dias apagados.

O nosso é um campo de mortos,

então.

E nós, oh,

nós estamos "vivos"

porque aqueles que vivos estavam

morreram daquele modo

na Casa da Morte

ainda não totalmente fechada.

O ânimo que resta

quanto a nós, nesta hora,

parece ser de recuo

e recusa de morrer

para escapar de viver apenas

e tão somente por nada

ou quase nada 
na espuma dos dias apagados.

O nosso é um campo de mortos,

então.

E nós, oh,

nós estamos "vivos"

porque aqueles que vivos estavam

morreram daquele modo

na Casa da Morte

ainda não totalmente fechada.

Então, isso quer dizer que

"estamos todos em perigo",

Pier Paolo,

neste momento do vírus

que nos transforma,

coroa de febre sobre a indiferença

de morte na hora crepuscular

do humano que nos torna

talvez menores do que já fomos

no silêncio dos moradores vizinhos

da Casa que continua de pé.

(..)

' Nasceu no Recife, em 1949. Escritor, poeta e cineasta, estreou com o poema longo Memória do Mar Sublevado (Editora Universitária, UFPE, 1973). É autor do premiado Aspades, Ets Etc, lançado em 1997, pela portuguesa Campo das Letras Editora, romance a que se seguiu $A$ Cabeça no Fundo do Entulho, distinguido com o primeiro Prêmio Bravo! de Literatura, em 1998. Vieram, nos anos seguintes, $A$ Múmia do Rosto Dourado do Rio de Janeiro (2001) e Armada América (2003), pela W11 Editora, SP, O Grau Graumann pela Editora Record e As Confissões de Lúcio pela Francis Editora. Como poeta, conquistou o Prêmio Nacional de Poesia da UBE/RJ, com Ecométrica, em 1984, e retornou ao poema longo em Vi uma foto de Anna Akhmátova, seguido de Mattinata (2012), coedição das Edições Nephelibata (SC) com a Sol Negro, editora de Natal que lançará, proximamente, o novo poema longo de Monteiro: Os Vivos(?) e os Mortos, do qual esta Revista apresenta, em primeira mão, o presente fragmento. 